\author{
JAN OLSZEWSKI \\ ORCID: 0000-0002-5704-7526 \\ Uniwersytet Rzeszowski \\ jolszew@univ.rzeszow.pl
}

\title{
Nowe instytucje standaryzacji informowania w ustawie o dostępie cyfrowym
}

\begin{abstract}
Abstrakt: Publikacja zawiera analizę ważniejszych instytucji z u.d.c.s.a.m.p.p., która wdraża dyrektywę Parlamentu Europejskiego i Rady (UE) 2016/2102 z dnia 26 października 2016 roku w sprawie dostępności stron internetowych i mobilnych aplikacji organów sektora publicznego. Generalnym celem ustawy jest opracowanie standardów w zakresie przekazywania informacji przez wskazane w niej organy publiczne w sposób najbardziej czytelny i uczciwy. W opisach poddano badaniom szczególnie kwestie normatywne w zakresie ujednolicania i zwiększania dostępności stron internetowych. W ramach analizy autor najpierw wykazuje nową siatkę pojęciową, następnie zaś najważniejsze instytucje prawne odnoszące się do cyfrowego informowania. W wielu miejscach dostrzega usterki legislacyjne, szczególnie w aspekcie rozmijania się tekstu ustawy z treściami dyrektywy. W wnioskach zaś przedstawiono kilka propozycji w zakresie dalszego doskonalenia przepływu informacji i komunikacji sfery publicznej z społeczeństwem.
\end{abstract}

Słowa kluczowe: prawo informacji, dostęp cyfrowy, dostępność informacji, rejestry publiczne, standaryzacja informacji, przekaz danych.

\section{Uwagi wstępne}

W prawie polskim powszechnie są już znane różnego rodzaju zakazy nieuczciwych praktyk rynkowych przejawiające się między innymi w informowaniu wprowadzającym w błąd. Zawarte są one w szczególności w ustawie z dnia 16 kwietnia 1993 roku o zwalczaniu nieuczciwej konkurencji ${ }^{1}$ czy też w ustawie z dnia 23 sierpnia 2007 roku o przeciwdziałaniu nieuczciwym praktykom rynkowym ${ }^{2}$. Istotne

${ }^{1}$ Dz.U. z 2019 r. poz. 1010, 1649.

2 Dz.U. z 2017 r. poz. 2070. 
wsparcie w zakresie ustalania zachowań nieuczciwych oprócz tu wymienionych aktów daje także bogata literatura ${ }^{3}$ i orzecznictwo odnoszące się do tych przepisów.

Niewiele jest w prawie norm prawnych wskazujących, jak informować w sposób uczciwy, a tym bardziej co należy zrobić, aby zapewnić najwyższe standardy w zakresie ujednolicania i zwiększania dostępności stron internetowych. W pewnym stopniu takie ustandaryzowane informacje są czytelniejsze, gdyż mogą ułatwić komunikację pomiędzy nadającymi, a odbiorcami informacji, ale także pozytywnie wpływać na rzetelność informacyjną.

Nawet jeśli takie normy odnajdziemy tu i ówdzie, to zwykle mają one charakter zaleceń branżowych. Jedynym wyjątkiem jest tu ustawa z dnia 30 maja 2014 roku o prawach konsumenta ${ }^{4}$, ale i ona ma ograniczony zakres podmiotowy, gdyż dotyczy jedynie konsumentów. Stan tej luki legislacyjnej został jednak znacznie ograniczony dzięki rozporządzeniu Rady Ministrów z dnia 12 kwietnia 2012 roku w sprawie Krajowych Ram Interoperacyjności, minimalnych wymagań dla rejestrów publicznych i wymiany informacji w postaci elektronicznej oraz minimalnych wymagań dla systemów teleinformatycznych ${ }^{5}$, a przede wszystkim dzięki ustawie z dnia 4 kwietnia 2019 roku o dostępności cyfrowej stron internetowych i aplikacji mobilnych podmiotów publicznych ${ }^{6}$. W szczególności ten drugi akt prawny kreuje wiele wyjątkowo użytecznych instytucji dla społeczeństwa, ale też i sfery publicznej. Myśląc o użyteczności, chodzi nam przede wszystkim o odbiorców informacji opracowanych na podstawie regulacji tam zawartych. Dużym ułatwieniem są także niektóre przepisy tego aktu dla organów publicznych, które są wykonawcami norm tej regulacji. Normy tam zawarte wręcz wymuszają wprowadzenie pewnych standardów. Takie rozwiązanie ograniczy stan niepewności, jak prezentować informacje publiczne. Ujednolicenie ułatwi także tworzenie materiałów informacyjnych, a potem ich odbiór. Poprzez standaryzację powinny także zmniejszyć się naciski polityczne na manipulowanie dotychczas niezdefiniowanym pojęciem. Ponadto standardy sprzyjają specjalizacji przez ukierunkowanie form prezentacji. Generalnie można stwierdzić, iż ustawa ta tworzy realne podwaliny do społeczeństwa cyfrowego, kreując wysokie standardy dostępu do informacji i usług. Podmioty udostępniające informacje i świadczące usługi, takie jak organy sektora publicznego, mogą dzięki tym rozwiązaniom jeszcze w większym stopniu wykorzystywać internet w celu tworzenia, gromadzenia i udostępniania

3 J. Olszewski, Geneza polskiej ustawy o zwalczaniu nieuczciwej konkurencji, „Rzeszowskie Zeszyty Naukowe. Prawo-Ekonomia” 17, 1995, s. 31-44; idem, Kilka uwag o oznaczaniu przedsiębiorstw, „Rzeszowskie Zeszyty Naukowe” 19, 1996, s. 33-48; idem, Nieuczciwa konkurencja, Warszawa 1995, s. 1-131; idem, Zwalczanie nieuczciwej konkurencji, Rzeszów 2007, s. 1-45; idem, Rozdział VII. Postępowanie w sprawach czynów nieuczciwej konkurencji, Rozdziat VIII. Przeciwdziałanie nieuczciwym praktykom rynkowym, [w:] Prawo gospodarcze. Kompendium, red. J. Olszewski, Warszawa 2016, s. 275-294.

4 Dz.U. z 2019 r. poz. 134, 730, 1495.

5 Dz.U. z 2012 r. poz. 526, akt ten obowiązuje od 2015 roku.

6 Dz.U. z 2019 r. poz. 848. 
szerokiego zakresu informacji i świadczenia w trybie online usług o podstawowym znaczeniu dla społeczeństwa ${ }^{7}$.

Celem niniejszego artykułu jest właśnie przedstawienie kilku wyjątkowo użytecznych instytucji z tego aktu, a jednocześnie porównanie jego norm z tymi, które ujęto $\mathrm{w}$ dyrektywie ${ }^{8}$ będącej podstawą do opracowania tej regulacji. Wynikiem takich analiz będzie nie tylko komentarz i ocena implementacji celów, ale także przedstawienie sugestii w zakresie nowatorskich rozwiązań organizacyjno-prawnych. Cele powyższe zostaną zrealizowane poprzez wykorzystanie metody teoretycznej, jaką jest analiza aktów prawnych i literatury, a także poprzez badania empiryczne zasobów internetowych zagranicznych instytucji publicznych ${ }^{9}$.

\section{Przegląd ważniejszych celów i tematów ustawy}

W literaturze od wielu lat sygnalizuje się, iż wiele stron internetowych organów publicznych ma nieaktualne dane. Ponadto dostrzega się też niejednolitość w prezentowaniu tych samych kwestii, a różnego rodzaju opisy umieszczane na takich stronach są w dużym stopniu niezrozumiałe.

Polski ustawodawca, pomimo iż podejmował już pewne działania legislacyj$n \mathrm{e}^{10}$, to jednak niewiele norm z przepisów o ujednoliceniu dostępu do informacji publicznych było egzekwowanych. W marginalnym też stopniu problemy te sygnalizowała nauka ${ }^{11}$. Czynnikiem nagłej zmiany w tym temacie okazała się — jak

${ }^{7}$ Uwagi wprowadzające do dyrektywy Parlamentu Europejskiego i Rady (UE) 2016/2102 z dnia 26 października 2016 roku w sprawie dostępności stron internetowych i mobilnych aplikacji organów sektora publicznego. Dz.Urz. UE L 327/1, pkt 1.

8 Ibidem.

9 W szczególności badane zostały strony internetowe niektórych organów publicznych Stanów Zjednoczonych Ameryki i Wielkiej Brytanii. (Na przykład https://www.ftc.gov/Federal Trade Commission, https://ico.org.uk/for-organisations/ Information Commissioners Office).

10 Należy tu przypomnieć, iż od 2015 roku obowiązuje rozporządzenie Rady Ministrów z dnia 12 kwietnia 2012 roku w sprawie Krajowych Ram Interoperacyjności, minimalnych wymagań dla rejestrów publicznych i wymiany informacji w postaci elektronicznej oraz minimalnych wymagań dla systemów teleinformatycznych.

$11 \mathrm{~W}$ publikacjach ukazywano potrzebę tworzenia we wszelkich procesach informacyjnych całości problemu, to znaczy łącznie z elementami negatywnymi, a także ujednolicania prezentacji; na przykład J. Olszewski, Instytucje klasyfikacji ratingowej w Unii Europejskiej $i$ w Indiach. Dwie drogi reformowania, [w:] Prawo azjatyckie z perspektywy Unii Europejskiej, red. M. Stępień, R. Łukasiewicz, Torun 2018, s. 85-112; idem, Nowe obowiazki informacyjne w zakresie tworzenia ładu korporacyjnego na przykładzie nowelizacji ustawy o KRS, [w:] Efektywność zarzadzania i nadzo$r u$ w spółce handlowej. W poszukiwaniu optymalnego ustroju spótki, red. K. Bilewska, Warszawa 2018, s. 30-52. 
zwykle — dyrektywa UE. Wskazała ona w pierwszej kolejności wiele wartości ${ }^{12}$, jakie powinny przejawiać się w procesie informowania cyfrowego, a następnie cele z zakresu praw materialnego i procesowego, dla których należy uchwalić specjalne akty prawne. Przede wszystkim było to wzmacnianie jednolitości, wiarygodności w zakresie treści umieszczanych na takich stronach. Dyrektywa ta została przez Polskę implementowana ${ }^{13}$ do uchwalonej w dniu 4 kwietnia 2019 roku ustawy o dostępności cyfrowej stron internetowych i aplikacji mobilnych podmiotów publicznych ${ }^{14}$ (dalej: ustawa lub u.d.c.s.a.m.p.p.). W tym akcie, po raz pierwszy, tak wszechstronnie i kompleksowo podano liczne obowiązki podmiotów mających bazy informacyjne, jeśli są udostępniane w postaci stron internetowych.

Celem niniejszej dyrektywy jest zapewnienie większej dostępności stron internetowych i mobilnych aplikacji organów sektora publicznego na podstawie wspólnych wymogów dostępności. W celu wyeliminowania fragmentacji rynku wewnętrznego konieczne jest zbliżenie środków krajowych na szczeblu unijnym na podstawie porozumienia $\mathrm{w}$ sprawie wymogów dostępności stron internetowych i mobilnych aplikacji organów sektora publicznego. Ograniczyłoby to niepewność, jakiej doświadczają programiści, i sprzyjałoby interoperacyjności. Zastosowanie neutralnych pod względem technologicznym wymogów dostępności nie będzie hamowało innowacyjności, lecz może ją wręcz stymulować.

Zbliżenie środków krajowych powinno również pozwolić unijnym organom sektora publicznego i przedsiębiorstwom na czerpanie korzyści gospodarczych i społecznych z rozszerzenia zakresu świadczenia usług online lub usług mobilnych na większą liczbę obywateli i klientów. Powinno to zwiększyć potencjał rynku wewnętrznego produktów i usług związanych z dostępnością stron internetowych i aplikacji mobilnych. Dzięki związanemu z tym rozwojowi rynku przedsiębiorstwa będą mogły przyczynić się do wzrostu gospodarczego i tworzenia nowych miejsc pracy na terytorium Unii. Wzmocnienie rynku wewnętrznego powinno zwiększyć atrakcyjność inwestycji w Unii. Na tańszym dostarczaniu produktów i usług związanych z dostępnością stron internetowych skorzystałyby też organy sektora publicznego. W znacznym stopniu regulacja ta ma pomóc osobom niepełno-

12 Tu można z pewnym wyprzedzeniem podać, iż wartości te w ustawie zostały znacznie ograniczone, tak jak w licznych aktach prawa w Polsce (więcej o koncepcji pomijania wartości w prawie polskim mówił prof. A. Powałowski na Zjeździe Katedr i Zakładów Publicznego Prawa Gospodarczego w dniu 23 września 2019 roku we Wrocławiu).

13 Niniejsza ustawa wdraża dyrektywę Parlamentu Europejskiego i Rady (UE) 2016/2102 z dnia 26 października 2016 roku w sprawie dostępności stron internetowych i mobilnych aplikacji organów sektora publicznego (Dz.Urz. UE L 327 z 2.12.2016, s. 1-2). Niniejszą ustawą zmienia się ustawę z dnia 17 lutego 2005 roku o informatyzacji działalności podmiotów realizujących zadania publiczne oraz ustawę z dnia 6 grudnia 2018 roku o zmianie ustawy o dowodach osobistych oraz niektórych innych ustaw. Zmiany tekstu jednolitego wymienionej ustawy zostały ogłoszone w Dz.U. z 2018 r. poz. 62, 1000, 1366, 1669, 1693, 2245, 2354 i 2500; oraz z 2019 r. poz. 303, 326 i 534.

14 Ustawa z dnia 4 kwietnia 2019 roku o dostępności cyfrowej stron internetowych i aplikacji mobilnych podmiotów publicznych, Dz.U. z 2019 r. poz. 848. 
sprawnym. Nowe prawo nakłada na podmioty publiczne, czyli wszystkie instytucje, które korzystają z pieniędzy publicznych, obowiązek takiego prezentowania informacji w internecie, aby wszyscy — bez wyjątku - mieli do nich dostęp. Chodzi tu w szczególności o osoby niewidome, słabo widzące, ale również o osoby niemogące posługiwać się myszką czy klawiaturą, nierozróżniające kolorów. Ze względu na duży zakres tematyczny ustawy do dalszej analizy szczególnie należy wyliczyć trzy grupy tematów.

Pierwsza dotyczy kwestii dostępowych i treściowych. Są to wymagania dostępności cyfrowej stron internetowych i aplikacji mobilnych podmiotów publicznych; wymagania dotyczące treści, przeglądu i aktualizacji deklaracji dostępności stron internetowych i aplikacji mobilnych podmiotów publicznych oraz ich publikacji.

Druga dotyczy organów i obowiązków, w szczególności w zakresie monitorowania. Wskazuje kompetencje organu właściwego w sprawach monitorowania zapewniania dostępności cyfrowej stron internetowych i aplikacji mobilnych, podmiotów publicznych oraz nadzoru nad stosowaniem przepisów ustawy ${ }^{15}$. Trzecia grupa to procedury i wyłączenia.

W ustawie jest także szeroki katalog włączeń generalnych lub cząstkowych. Generalne wyłączenia dotyczą na przykład dostawców usług w zakresie mediów.

\section{Ważniejsze pojęcia}

Rozrost technologii informatycznych spowodował, iż w ich opisywaniu pojawiło się wyjątkowo dużo zróżnicowanych pojęć. Aby stan ten nie doprowadził do chaosu, w niniejszej ustawie przedstawiono jednolite pojęcia, które związane są z całą sferą internetu. Należy w tym miejscu wskazać, iż ustalono pojęcie strony internetowej - jest to zbiór uporządkowanych logicznie, połączonych z sobą przez nawigację oraz linki, elementów prezentowanych za pomocą przeglądarki internetowej pod jednolitym adresem elektronicznym.

Do innych istotnych definicji należy też zaliczyć szczególnie te związane z oprogramowaniem. Przykładem jest pojęcie aplikacji mobilnej — jest to publicznie dostępne oprogramowanie $z$ interfejsem dotykowym, zaprojektowane do wykorzystania na przenośnych urządzeniach elektronicznych, z wyłączeniem aplikacji przeznaczonych do użytku na przenośnych komputerach osobistych; elementem zaś strony internetowej lub aplikacji mobilnej jest tekst, grafika, wykresy, mapy, multimedia, animacje, pliki oraz narzędzia do interaktywnego przesyłania danych. Kolejną ważną grupą są pojęcia związane $\mathrm{z}$ dostępnością cyfrową. Podmioty publiczne zapewniają przede wszystkim dostępność cyfrową. Aby aspekt ten był w pełni zro-

15 Na przykład zasady monitorowania zapewniania dostępności cyfrowej stron internetowych lub aplikacji mobilnych oraz prowadzenia sprawozdawczości w zakresie dostępności cyfrowej. 
zumiały, wyliczono tu szereg wymagań. Ich realizacja następuje przez wprowadzenie na stronę internetową lub aplikację mobilną określonych sprawności ${ }^{16}$.

\section{Deklaracja dostępności jako nowy obowiązek podmiotów podlegających pod przepisy ustawy}

Zgodnie z art. 2 ustawę stosuje się do: 1. jednostek sektora finansów publicznych, w rozumieniu przepisów ustawy z dnia 27 sierpnia 2009 roku o finansach publicznych ${ }^{17} ; 2$. innych niż określone w pkt 1 państwowych jednostek organizacyjnych nieposiadających osobowości prawnej; 3. innych niż określone w pkt 1 osób prawnych, utworzonych w szczególnym celu zaspokajania potrzeb o charakterze powszechnym, niemających charakteru przemysłowego ani handlowego, jeżeli podmioty, o których mowa w tym przepisie oraz w pkt 1 i 2, pojedynczo lub wspólnie, bezpośrednio albo pośrednio przez inny podmiot: a) finansują je w ponad $50 \%$ lub b) posiadają ponad połowę udziałów albo akcji, lub c) sprawują nadzór nad organem zarządzającym, lub d) mają prawo do powoływania ponad połowy składu organu nadzorczego lub zarządzającego; 4. związków podmiotów, o których mowa w pkt 1-3, 5. organizacji pozarządowych, o których mowa w art. 3 ust. 2 ustawy z dnia 24 kwietnia 2003 roku o działalności pożytku publicznego i o wolontariacie ${ }^{18}$, prowadzących działalność w sferze zadań publicznych wymienionych w art. 4 ust. 1 pkt 6, 7 lub 10 tej ustawy - posiadających strony internetowe lub aplikacje mobilne, lub zarządzających elementami stron internetowych, lub aplikacji mobilnych zamieszczonymi w środowisku umożliwiającym zapewnienie dostępności cyfrowej treści, zwanych dalej „podmiotami publicznymi”.

Jednostki tu wymienione zostały zobowiązane przez ustawodawcę do zapewniania dostępności cyfrowej elementów stron internetowych i niektórych aplikacji mobilnych. Ponadto zobligowano je do umieszczenia informacji na stronie podmiotowej Biuletynu Informacji Publicznej lub wybranej stronie internetowej jednostki samorządu terytorialnego. Nowatorskim rozwiązaniem jest swoista samoocena każdego tak zobowiązanego podmiotu publicznego w zakresie dostępności internetowej. Powstaje ona samodzielnie i przyjmuje postać deklaracji dostępności.

Podmioty publiczne dokonują przeglądu i aktualizacji deklaracji dostępności do dnia 31 marca każdego roku oraz niezwłocznie, w każdym przypadku,

16 Zgodnie z art. 5.1 ustawy dostępność cyfrowa strony internetowej i aplikacji mobilnej polega na zapewnieniu ich funkcjonalności, kompatybilności, postrzegalności i zrozumiałości.

17 Dz.U. z 2017 r. poz. 2077, z późn. zm.

18 Dz.U. z 2019 r. poz. 688. 
gdy strona internetowa lub aplikacja mobilna podlega zmianom mogącym mieć wpływ na jej dostępność cyfrową ${ }^{19}$.

\section{Prawo do żądania dostępu}

Jednym z istotnych uprawnień, jakie daje u.d.c.s.a.m.p.p., jest prawo do żądania dostępu ${ }^{20}$ — wskazanej strony internetowej, aplikacji mobilnej lub elementu strony internetowej, lub aplikacji mobilnej, a także innych elementów. Zapewnienie dostępności cyfrowej strony internetowej, aplikacji mobilnej lub elementu strony internetowej, lub aplikacji mobilnej podmiotu publicznego następuje bez zbędnej zwłoki, jednak nie później niż w terminie siedmiu dni od dnia wystąpienia z żądaniem.

Ustawodawca przewidział także nadzwyczajne utrudnienia, które pojawiają się w przypadkach różnego typu awarii. Dlatego w art. 18 ust. 4 u.d.c.s.a.m.p.p. wskazano cały katalog czynności, jakie należy podjąć, jeżeli nie zapewni się pełnej dostępności cyfrowej strony internetowej, aplikacji mobilnej (lub elementu strony internetowej, lub aplikacji mobilnej) podmiotu publicznego. W takiej sytuacji $\mathrm{w}$ terminach wskazanych $\mathrm{w}$ ustawie podmiot publiczny niezwłocznie powinien powiadomić osobę występującą z żądaniem o przyczynach opóźnienia oraz terminie, w którym zapewni dostępność cyfrową wskazanej strony internetowej (aplikacji mobilnej lub elementu strony internetowej, lub aplikacji mobilnej). Termin ten nie może jednak być dłuższy niż dwa miesiące od dnia wystąpienia z żądaniem.

\section{Odmowa zapewnienia dostępności cyfrowej}

W ustawie przewidziano szereg wyjątków i wartą uwagi instytucję odmowy zapewnienia dostępności cyfrowej. W przypadku odmowy zapewnienia dostępności cyfrowej strony internetowej, aplikacji mobilnej lub wskazanego elementu strony internetowej, lub aplikacji mobilnej podmiotu publicznego wskazanych $\mathrm{w}$ żądaniu, albo w przypadku odmowy skorzystania $\mathrm{z}$ alternatywnego sposobu dostępu przez osobę występującą z żądaniem, zgodnie z ust. 6, osoba ta ma prawo

19 Na podstawie art. 11 u.d.c.s.a.m.p.p.

${ }^{20}$ Art. 18.1: „Każdy ma prawo wystąpić do podmiotu publicznego z żądaniem zapewnienia dostępności cyfrowej wskazanej strony internetowej, aplikacji mobilnej lub elementu strony internetowej, lub aplikacji mobilnej, w tym elementów, o których mowa w art. 3 ust. 2, oraz elementów niedostępnych cyfrowo na podstawie art. 8 ust. 1, albo o jego udostępnienie za pomocą alternatywnego sposobu dostępu, o którym mowa w art. 7" u.d.c.s.a.m.p.p. 
do złożenia do podmiotu publicznego skargi ${ }^{21} \mathrm{~W}$ sprawie zapewnienia dostępności cyfrowej strony internetowej, aplikacji mobilnej lub elementu strony internetowej, lub aplikacji mobilnej. W ten sposób, oprócz podmiotów prywatnych ${ }^{22}$, jakim są przedsiębiorcy, za braki w informowaniu według standardu odpowiadać mogą także podmioty publiczne.

\section{Wnioski}

Podsumowując regulację, można przedstawić kilka uwag. Przede wszystkim odnosić się będą one do aksjologii oraz sfery pojęciowej, następne zaś do niektórych aspektów w zakresie podmiotowym i przedmiotowym. Oprócz pewnych usterek w ramach uwag odniesiono się także do regulacji uzupełniających oraz pokreślono bardzo praktyczne rozwiązanie dające podstawę do pewnych włączeń.

1. W ustawie prawodawca dopuścił się znacznego zawężenia aksjologicznego. Stan taki powstał z powodu ograniczania się w treści ustawy jedynie do prezentacji rozwiązań instytucjonalnych i procesowych. Należy stwierdzić, że doktryna ${ }^{23}$ wielokrotnie wykazywała, iż charakterystyczną cechą większości polskich ustaw jest niczym nieuzasadnione pomijanie aspektów z zakresu aksjologii. Stan taki (czyli ograniczanie się w nich jedynie do takich właśnie elementów) zdecydowanie należy ocenić krytycznie. Aby uzdrowić ten stan, wskazana jest nowelizacja odwołania się do przynajmniej kilku aksjologicznych odniesień z dyrektywy. Szczególnie powinno się odwołać do tekstu wprowadzenia do dyrektywy ${ }^{24}$. Wskazuje on, że żaden z przepisów niniejszej dyrektywy nie ma na celu ograniczania wolności słowa ani wolności i pluralizmu mediów w zakresie, w jakim są one zagwarantowane w Unii

21 Do skarg rozpatrywanych w postępowaniach w sprawie zapewnienia dostępności cyfrowej strony internetowej, aplikacji mobilnej lub elementu strony internetowej, lub aplikacji mobilnej stosuje się przepisy działu VIII ustawy z dnia 14 czerwca 1960 roku - Kodeks postępowania administracyjnego (Dz.U. z 2018 r. poz. 2096; oraz z 2019 r. poz. 60, 730). Do zapewnienia alternatywnego sposobu dostępu do wskazanego elementu strony internetowej lub aplikacji mobilnej przepisy ust. 3-8 stosuje się odpowiednio.

22 Szerzej na temat obowiązków informacyjnych przedsiębiorców, a następnie ich odpowiedzialności zob. J. Olszewski, Wybrane regulacje prawa karnego użyteczne $w$ zwalczaniu agresywnych czynów nieuczciwej konkurencji, [w:] Wspótczesne wyzwania prawa ochrony konkurencji - między teoria a praktyka, red. J. Olszewski, Rzeszów 2014, s. 15-23. Natomiast nowe rodzaje obowiązków naświetlono w: idem, Obowiązki informacyjne związane z roszczeniem o odszkodowanie za szkody wyrządzone przez naruszenie prawa konkurencji, [w:] Przedsiębiorca w meandrach prawa. Aktualne problemy i kierunki zmian, red. E. Feret, M. Sagan, Rzeszów 2017, s. $89-129$.

${ }^{23}$ Stanowisko takie przedstawił między innymi prof. A. Powałowski na Zjeździe Katedr i Zakładów Publicznego Prawa Gospodarczego w dniu 23 września 2019 roku we Wrocławiu.

${ }^{24}$ Zgodnie z pkt 24 wprowadzenia do dyrektywy. 
i w państwach członkowskich, w szczególności na mocy art. 11 Karty praw podstawowych Unii Europejskiej (dalej: Karta). Warte uwagi są też inne odniesienia do aksjologii. Na przykład zgodnie z pkt 28 bardzo wyraźnie wskazano, iż niniejsza dyrektywa, poza tym że zachęca organy sektora publicznego do zapewnienia dostępności wszelkich treści, nie ma na celu ograniczenia treści, które organy sektora publicznego umieszczają na swoich stronach internetowych lub w aplikacjach mobilnych wyłącznie do treści, które są dostępne. Gdy dodawane są treści niedostępne, organy sektora publicznego powinny, w zakresie, w jakim jest to racjonalnie możliwe, dodawać na swoich stronach internetowych lub w swoich aplikacjach mobilnych dostępne alternatywy.

2. Oprócz pomijania aspektów aksjologicznych w treści polskiej ustawy nie wskazano wyraźnie także wielu kwestii organizacyjnych co do sugerowanego rozszerzania zakresu ustawy. Warto tu przypomnieć, że dyrektywie zachęca się państwa członkowskie, aby mogły rozszerzać zakres stosowania niniejszej dyrektywy na inne rodzaje stron internetowych i aplikacji mobilnych, w szczególności na strony intranetowe lub ekstranetowe oraz na aplikacje mobilne nieobjęte niniejszą dyrektywą, a które są przeznaczone do stosowania i stosowane przez ograniczoną liczbę osób do wykorzystania w miejscu pracy lub w ramach nauki oraz do utrzymywania lub wprowadzania, zgodnie z przepisami Unii, środków wykraczających poza minimalne wymogi dostępności stron internetowych i aplikacji mobilnych ${ }^{25}$. Należy też zachęcać państwa członkowskie do rozszerzania stosowania niniejszej dyrektywy na podmioty prywatne, które oferują urządzenia i usługi ogólnie dostępne lub powszechnie zapewniane, w tym w dziedzinie opieki zdrowotnej, opieki nad dziećmi, włączenia społecznego i zabezpieczenia społecznego, a także w sektorze transportu oraz energii elektrycznej, gazu, ciepła, wody, komunikacji elektronicznej i usług pocztowych, ze szczególnym uwzględnieniem usług, o których mowa w art. 8-13 dyrektywy 2014/25/UE.

3. Pomiędzy tekstem dyrektywy a ustawy jest wiele różnic — w szczególności dotyczy to kwestii pojęciowych. Należy tu zaznaczyć, iż nawet pojęcia podstawowe są nieco odmienne, na przykład postrzegalność, funkcjonalność, zrozumiałość czy integralność. Wnikliwa analiza obu definicji wskazuje, że generalnie dotyczą tego samego. W ustawie wydaje się, iż sformułowane są nieco prościej. $\mathrm{W}$ ten sposób definicja $\mathrm{z}$ dyrektywy może pełnić funkcję uzupełniającą.

4. Należy podkreślić, że nawet podmioty korzystające z pewnego wyłączenia powinny na swoich stronach prezentować informacje publiczne, spełniając wymagania, jakie wynikają z innych dyrektyw i konwencji ONZ. W szczególności chodzi tu o dyrektywę Rady 2000/78/WE ${ }^{26}$ i konwencję ONZ — zawierają one

25 Na podstawie pkt 34 wprowadzenia do dyrektywy.

26 Dyrektywa Rady 2000/78/WE z dnia 27 listopada 2000 roku ustanawiająca ogólne warunki ramowe równego traktowania w zakresie zatrudnienia i pracy (Dz.U. L 303 z 2.12.2000, s. 16). 
wymogi dotyczące „racjonalnych usprawnień” i powinny być spełniane w zakresie, w jakim to konieczne, w szczególności w odniesieniu do miejsc pracy i nauki.

5. Ze względu na to, że w ciągu dwóch lat wszystkie strony urzędów będą już dostępne cyfrowo, wnioski należy podsumować postulatem popularyzacji nowych rozwiązań dostępowych. Działania takie są konieczne, aby społeczeństwo miało świadomość istnienia wielu nowatorskich ułatwień informacyjnych, a poprzez to powszechniej korzystało z zasobów informacji publicznej. Popularyzacja jest wprost zalecana w pkt 47 wprowadzenia dyrektywy ${ }^{27}$. Wskazane jest także rozwijanie prawa o informacji - uzasadnienie takiego postulatu widoczne jest w pracach jak na razie niewielkiej grupy pracowników nauki ${ }^{28}$.

\section{Bibliografia}

Cyrul W., Consolidation of legal documents in an electronic format, [w:] Information technology and law, red. W. Cyrul, Kraków 2014.

Cyrul W., Duda J., Opiła J., Pełech-Pilichowski T., Informatyzacja tekstu prawa: perspektywy zastosowania języków znacznikowych, Warszawa 2014.

Janowski J., Technologia informacyjna dla prawników i administratywistów. Szanse i zagrożenia elektronicznego przetwarzania danych w obrocie prawnym i działaniu administracji, Warszawa 2009.

27 Wskazano tam, że państwa członkowskie powinny podjąć środki niezbędne w celu popularyzowania wiedzy o programach szkoleniowych odnoszących się do dostępności stron internetowych i aplikacji mobilnych, a przeznaczonych dla odpowiednich zainteresowanych stron i pracowników odpowiedzialnych za dostępność stron internetowych lub aplikacji mobilnych, i w celu promowania takich programów. Należy przeprowadzić konsultacje z odpowiednimi zainteresowanymi stronami lub włączać je w przygotowywanie treści programów szkoleń dotyczących dostępności oraz programów popularyzatorskich w tej dziedzinie.

28 W szczególności należy tu wymienić: J. Petzel, Informatyka prawnicza. Zagadnienia teorii i praktyki, Warszawa 1999, s. 13-333; W. Wiewiórkowski, G. Wierczyński, Informatyka prawnicza. Technologia informacyjna dla prawników i administracji publicznej, Kraków 2006, s. 29-31; T. Szewc, Publicznoprawna ochrona informacji, Warszawa 2007; J. Janowski, Technologia informacyjna dla prawników i administratywistów. Szanse i zagrożenia elektronicznego przetwarzania danych $w$ obrocie prawnym i działaniu administracji, Warszawa 2009; W. Cyrul, Consolidation of legal documents in an electronic format, [w:] Information technology and law, red. W. Cyrul, Kraków 2014, s. 79-93; W. Cyrul, J. Duda, J. Opiła, T. Pełech-Pilichowski, Informatyzacja tekstu prawa: perspektywy zastosowania języków znacznikowych, Warszawa 2014, LEX; M. Kłodawski, Pojęcie informacji w naukach teoretycznoprawnych, https://depot.ceon.pl/bitstream/handle/123456789/316/Maciej_Klodawski_-_Pojecie_informacji_w_naukach_teoretycznoprawnych. pdf (dostęp: 10.09.2019); J. Marcinkowska, Roszczenie informacyjne w niemieckiej ustawie o prawie autorskim, ZNUJ PPWI 2010, z. 110, s. 94; J. Olszewski, Nowe obowiazki informacyjne w prawie publicznym, [w:] Sektory infrastrukturalne - problematyka prawna, red. M. Królikowska-Olczak, Warszawa 2018, s. 93-112; idem, Obowiazki informacyjne w mediacjach konsumenckich, [w:] Doświadczenia arbitrażu i mediacji. Perspektywa prywatnoprawna oraz publicznoprawna - między teoria a praktyka. Księga Pamiątkowa ku czci Prof. Jana Łukasiewicza, red. Ł. Błaszczak, J. Olszewski, R. Morek, Rzeszów 2018, s. 391-418. 
Kłodawski M., Pojęcie informacji w naukach teoretyczno prawnych, https://depot.ceon.pl/bitstream/handle/123456789/316/Maciej_Klodawski_-_Pojecie_informacji_w_naukach_teoretycznoprawnych.pdf (dostęp: 10.09.2019).

Marcinkowska J., Roszczenie informacyjne $w$ niemieckiej ustawie o prawie autorskim, ZNUJ PPWI 2010, z. 110.

Olszewski J., Geneza polskiej ustawy o zwalczaniu nieuczciwej konkurencji, „Rzeszowskie Zeszyty Naukowe. Prawo-Ekonomia" 17, 1995.

Olszewski J., Instytucje klasyfikacji ratingowej w Unii Europejskiej $i$ w Indiach. Dwie drogi reformowania, [w:] Prawo azjatyckie z perspektywy Unii Europejskiej, red. M. Stępień, R. Łukasiewicz, Toruń 2018.

Olszewski J., Kilka uwag o oznaczaniu przedsiębiorstw, „Rzeszowskie Zeszyty Naukowe” 19, 1996.

Olszewski J., Nieuczciwa konkurencja, Warszawa 1995.

Olszewski J., Nowe obowiązi informacyjne w prawie publicznym, [w:] Sektory infrastrukturalne - problematyka prawna, red. M. Królikowska-Olczak, Warszawa 2018.

Olszewski J., Nowe obowiazki informacyjne w zakresie tworzenia ładu korporacyjnego na przykładzie nowelizacji ustawy o KRS, [w:] Efektywność zarzadzania i nadzoru w spółce handlowej. W poszukiwaniu optymalnego ustroju spótki, red. K. Bilewska, Warszawa 2018.

Olszewski J., Obowiązki informacyjne w mediacjach konsumenckich, [w:] Doświadczenia arbitrażu i mediacji. Perspektywa prywatnoprawna oraz publicznoprawna - między teoria a praktyka. Księga Pamiątkowa ku czci Prof. Jana Łukasiewicza, red. Ł. Błaszczak, J. Olszewski, R. Morek, Rzeszów 2018.

Olszewski J., Obowiąki informacyjne zwiąane z roszczeniem o odszkodowanie za szkody wyrzadzone przez naruszenie prawa konkurencji, [w:] Przedsiębiorca w meandrach prawa. Aktualne problemy i kierunki zmian, red. E. Feret, M. Sagan, Rzeszów 2017.

Olszewski J., Rozdział VII. Postępowanie w sprawach czynów nieuczciwej konkurencji, Rozdziat VIII. Przeciwdziałanie nieuczciwym praktykom rynkowym, [w:] Prawo gospodarcze. Kompendium, red. J. Olszewski, Warszawa 2016.

Olszewski J., Wybrane regulacje prawa karnego użyteczne w zwalczaniu agresywnych czynów nieuczciwej konkurencji, [w:] Wspótczesne wyzwania prawa ochrony konkurencji - między teoria a praktyka, red. J. Olszewski, Rzeszów 2014.

Olszewski J., Zwalczanie nieuczciwej konkurencji, Rzeszów 2007.

Petzel J., Informatyka prawnicza. Zagadnienia teorii i praktyki, Warszawa 1999.

Szewc T., Publicznoprawna ochrona informacji, Warszawa 2007.

Wiewiórkowski W., Wierczyński G., Informatyka prawnicza. Technologia informacyjna dla prawników i administracji publicznej, Kraków 2006.

\title{
New information standardization institutions in the Digital Access Act
}

\author{
Summary
}

This publication includes the analysis of more important institutions from the Digital Access Act. The above-mentioned Act implements Directive (EU) 2016/2102 of the European Parliament and of the Council of 26th October 2016 on accessibility of websites and mobile applications of public sector bodies. The main purpose of the Act is to instruct how to inform in a clear and simple manner in order to achieve the highest level in standardization and improving web site accessibility. In his analysis, the author describes a set of new definitions and absolutely radical and 
new conceptions for digital access regulations. In some places the author indicates problems with new regulations mainly when the text of the Act differs from the directive's intentions and goals. At the end of the analysis there are some proposals to improve the flow of information and communication between all kinds of public organs.

Keywords: Information law, digital access, information availability, public registers, information standardization, data transmission. 